DOI: $10.2478 / \mathrm{v} 10025-010-0017-6$

JOURNAL OF WATER

AND LAND DEVELOPMENT

J. Water Land Dev. No. 13a, 2009: 19-40

\title{
Methods of estimating the elements of water balance in a forested catchment basin
}

\author{
Bolestaw OSUCH, Wiestaw GACEK, Anna HOMA, \\ Marta CEBULSKA, Robert SZCZEPANEK, Anna HEBDA-MALOCHA
}

Cracow University of Technology, Institute of Water Engineering and Water Management, ul. Warszawska 24, 31-155 Kraków, Poland; e-mail: wieslaw.gadek@iigw.pl, marta.cebulska@iigw.pl, robert.szczepanek@iigw.pl

\begin{abstract}
The paper presents basic hydrological processes of rainfall-runoff transformation in experimental watershed of the Trzebunka stream. Several field experiments were made to determine basic hydrological parameters, The influence of atmospheric circulation on spatial distribution of precipitation was investigated. Attempt was made to determine the influence of forest vegetation, undergrowth, forest litter retention and surface retention on water loss in the catchment. Water retention capacity of soil was also estimated. Developed mathematical model of rainfall-runoff transformation was used in several simulations. This allowed evaluating the effect of atmospheric circulation and spatial rainfall distribution on water balance, the influence of vegetation cover with forest litter on water runoff and the effect of forest litter alone in a hypothetical scenario of forest cutting.
\end{abstract}

Key words: interception, precipitation, retention, water balance

\section{INTRODUCTION}

From hydrologic point of view the proper water balance of a given catchment basin formulated for the long term period, for a year of any other time period, is the basis for the description of hydrologic processes, in particular of total and extreme water outflow. The point is that the runoff should not be described by models of optimised parameters but by parameters actually established for the catchment in question.

Runoff balance often does not sum up when using optimised parameters even if modelled runoff agrees with the measured. Proper descriptions of water balance elements allow for drawing respective conclusions for scientific debates and economic activities. This makes the basis for estimating the components of complete water balance. One should thus aim at applying integral models with possibly full description of parameters based on physical features decisive for water retention 
and its distribution into runoff and balance losses. There is a need of assessing water balance of forested catchment (or covered by other type of vegetation) through physical description of hydrologic processes transforming rainfall into runoff with special reference to mountain catchments.

It is not possible to undertake actions to protect natural environment and to predict environmental response to human impact like pollutant input without detailed description of rainfall-runoff transformation and without an assessment of the volume of natural retention reservoirs in the catchment. It is also hard to imagine full and unambiguous scientific study on drought or regulation of water relations in a catchment without considering water retention capacity or evapotranspiration by definite tree (or plant in general) species. One should remind here the role of plant cover for controlling flood runoff. An assessment of water distribution according to classic equation: precipitation (input) equals runoff plus evaporation plus the increase of retention (output) seems insufficient due to increasing role of the way and amount of water retained in the catchment.

Due to easy recognition of particular elements this basic equation can be transformed into the form:

$$
H=P-E-\Delta R
$$

where:

$H$ - runoff from the catchment, $\mathrm{mm}$;

$P$ - atmospheric precipitation, $\mathrm{mm}$;

$E$ - evaporation, $\mathrm{mm}$;

$\Delta R$ - change of retention, $\mathrm{mm}$.

Runoff is one of the values which we measure in a satisfactory manner. Due to their spatial character, other values are hard to estimate. In water balances for longer time periods the retention variability can be omitted.

The aim of field studies carried out in the Trzebuńka stream catchment basin was to assess the importance of the effect of forest litter interception and of spatial distribution of rainfall with the consideration of atmospheric circulation on water balance in this mountain cachment.

Earlier studies carried out in this catchment showed significant impact of forest on runoff. High variability (without constant trends) of rainfall observed in these studies was attributed to the effect of circulation on spatial rainfall distribution. It was concluded that these factors need more detailed field studies to unambiguously establish the size of this impact on runoff. Own studies and mathematical model WISTOO were the basis for all analyses.

Elaborated model of rainfall-runoff transformation of distributed parameters was used to perform a set of simulations. It served i.a. to assess:

- the effect of atmospheric circulation on spatial distribution of rainfall - Scenario B, - the role of forest litter interception in balance calculations - Scenario C. 
Moreover, a simulation was performed of hypothetical situation - forest litter interception without forest interception - which may occur when the forest is cut down - Scenario D.

\section{GENERAL INFORMATION ON STUDY CATCHMENT}

The Trzebuńka stream catchment of an area of $33 \mathrm{~km}^{2}$ is situated south-west of Myślenice in the Beskid Średni. The stream valley running parallel separates the range of Koton to the south from the range of Sularzowa Gora to the north. The highest point in the catchment is Koton ( $868 \mathrm{~m}$ a.s.1.). Outflow to the Raba River is situated at $305 \mathrm{~m}$ a.s.l. The whole catchment area is cut by a dense network of $\mathrm{V}$-shaped valleys. Average slope inclination is from $9^{\circ}$ to $12^{\circ}$. Maximum inclination of $30^{\circ}$ or more occurs on slopes of northern exposition in the range of Koton. Minimum inclination can be found in the Trzebuńka valley and on broad prominences in ridge parts (HOMA, 1995).

Department of Hydrology of the Institute of Engineering and Water Management, Technical University in Kraków had two meteorological stations and four rainfall gauges in the Trzebuńka catchment (Fig. 1). The longest series of continuous records is in the possession of the station in Stróża (since 1973). Data from this station were used in this paper.

According to HESS'S classification (1965) two climatic storeys can be distinguished;

$\mathrm{a}$ - moderately warm storey - up to the height of $680 \mathrm{~m}$,

$\mathrm{b}$ - moderately cool storey - up to the height of $1100 \mathrm{~m}$.

With respect to land relief and exposition local climatic variants are determined by:

- northern slopes which are cooler, more humid and retain snow cover for longer period than the southern slopes,

- valleys which are cooler and drier than convex forms at the same elevation a.s.l. Moderately cool storey occurs only in ridge parts and occupies small areas.

One of the most important factors for water relations in the area are precipitations. Their amount, temporal distribution, type and intensity are decisive for water phenomena of a given terrain. Mean precipitation for 35 years (1973-2007) in the station in Stróża was $861.5 \mathrm{~mm}$. Maximum precipitation occurred in summer, minimum - in winter. Snow precipitation occurs mainly in December, January and February but starts in the $2^{\text {nd }}$ decade of November and lasts until the $1^{\text {st }}$ decade of April.

The number of days with snow cover varies from 70 to 80 but is significantly related to local conditions i.e. to relief, slope exposition and forest cover. Snow cover stays longest in forest areas which thus become runoff regulators during the snow-melt period. 


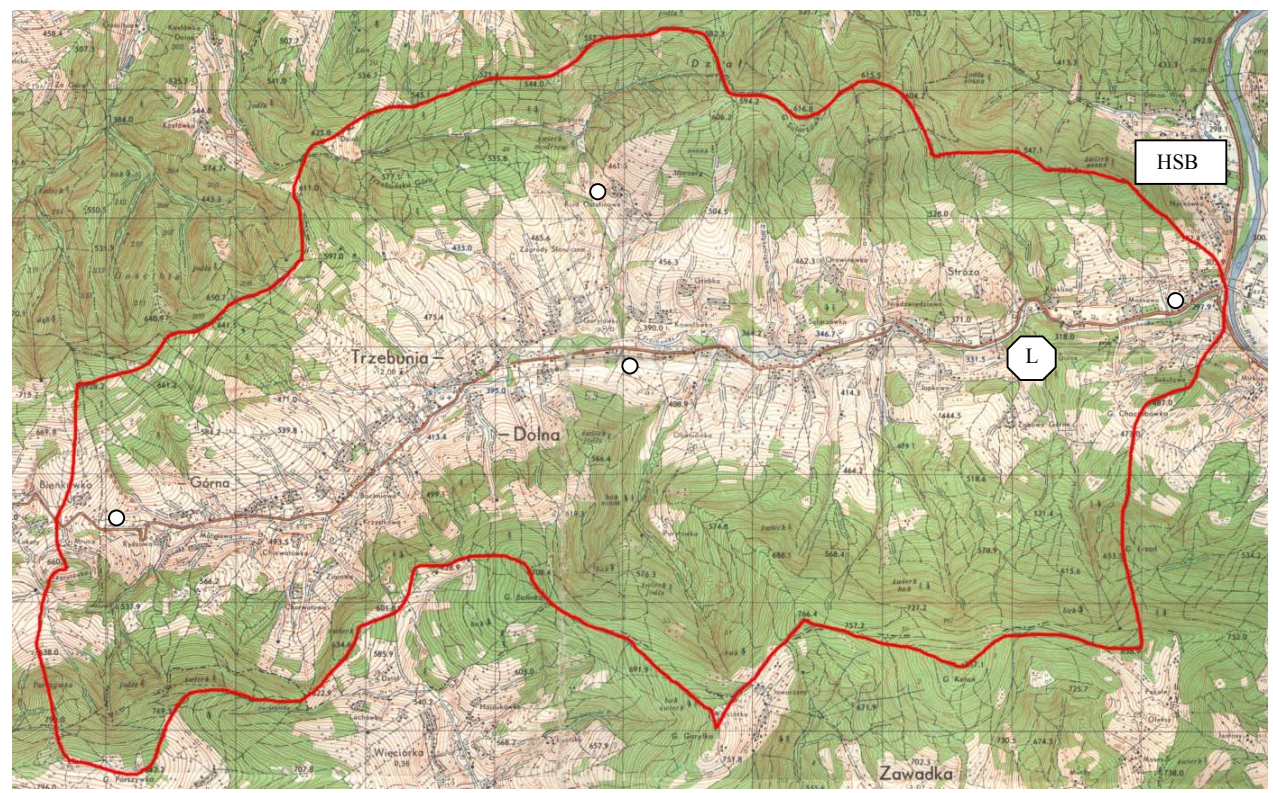

HSB - Hydrological Station in Stróża, L - experimental plot in Stróża, O- precipitation station

Fig. 1. The Trzebuńka stream catchment basin

Annual mean air temperature is from $5^{\circ} \mathrm{C}$ in the ridge parts to $8^{\circ} \mathrm{C}$ in the valley. Mean air temperature in the Stróża station for the period 1973-2006 was $7.7^{\circ} \mathrm{C}$. Mean temperature of the warmest month (July) is $17.2^{\circ} \mathrm{C}$, mean of the coldest month (January) is $-1.2^{\circ} \mathrm{C}$. The extreme values are: maximum - from $26^{\circ} \mathrm{C}$ to $34^{\circ} \mathrm{C}$, minimum - from $-25^{\circ} \mathrm{C}$ to $-32^{\circ} \mathrm{C}$. There are 50 to 60 frost days (maximum temperature below $0^{\circ} \mathrm{C}$ ) on average in the area.

Wind velocity is closely related to local conditions. Annual records of wind velocity indicate distinct maximum in winter and minimum in summer. Prevailing wind directions are westerly and south-westerly. Winds of higher velocities often blow from southern directions. These are typically warm and dry foehn winds that reach the Tatras. The number of days with strong winds (above $10 \mathrm{~m} \cdot \mathrm{s}^{-1}$ ) varies from 20 to 25 .

\section{MATEMATICAL MODEL OF RAINFALL-RUNOFF TRANSFORMATION „WISTOO”}

DESCRIPTION OF THE WISTOO MODEL

Model WISTOO is adapted to perform simulations of rainfall-runoff transformation with an hourly step for mountain and sub-mountain catchments. Simula- 
tions can be made for long time periods ( $7-8$ months) covering the whole summer half-year. The following digital thematic layers are used during calculations (see Fig. 2):

- digital model of the area NMT (2d),

- river network (2c),

- structure of the grounds (2b),

- land use (2a) (GĄDEK, 2002; OZGA-ZIELIŃSKA et al., 2002).

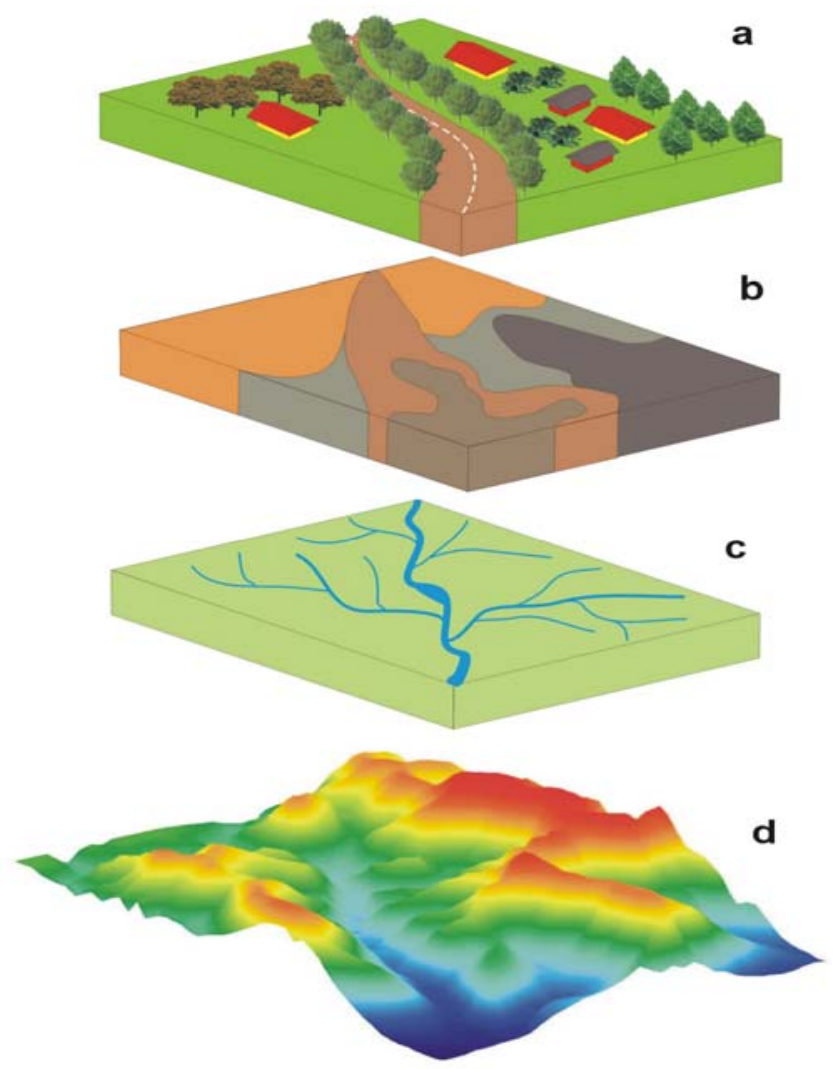

Fig. 2. Numerical thematic layers used in calculation with the WISTOO model

The number of thematic layers may be enlarged depending on the range of performed simulations (individual model applications).

Catchment (its vertical projection) is divided into square elements (rasters) of the size intended by the programme user. Maximum number of these elements is 4 million.

Computer implementation of the model enables to follow in time such parameters as: 
- flow hydrographs in 25 selected (control) cross-sections of rivers,

- spatial distribution of: net rainfall, velocity and depth of water in surface or subsurface runoff and soil moisture

Model's structure was based on a scheme of water circulation in catchment generalised to the form presented in Fig. 3. Model input consists of datasets containing (Fig. 4):

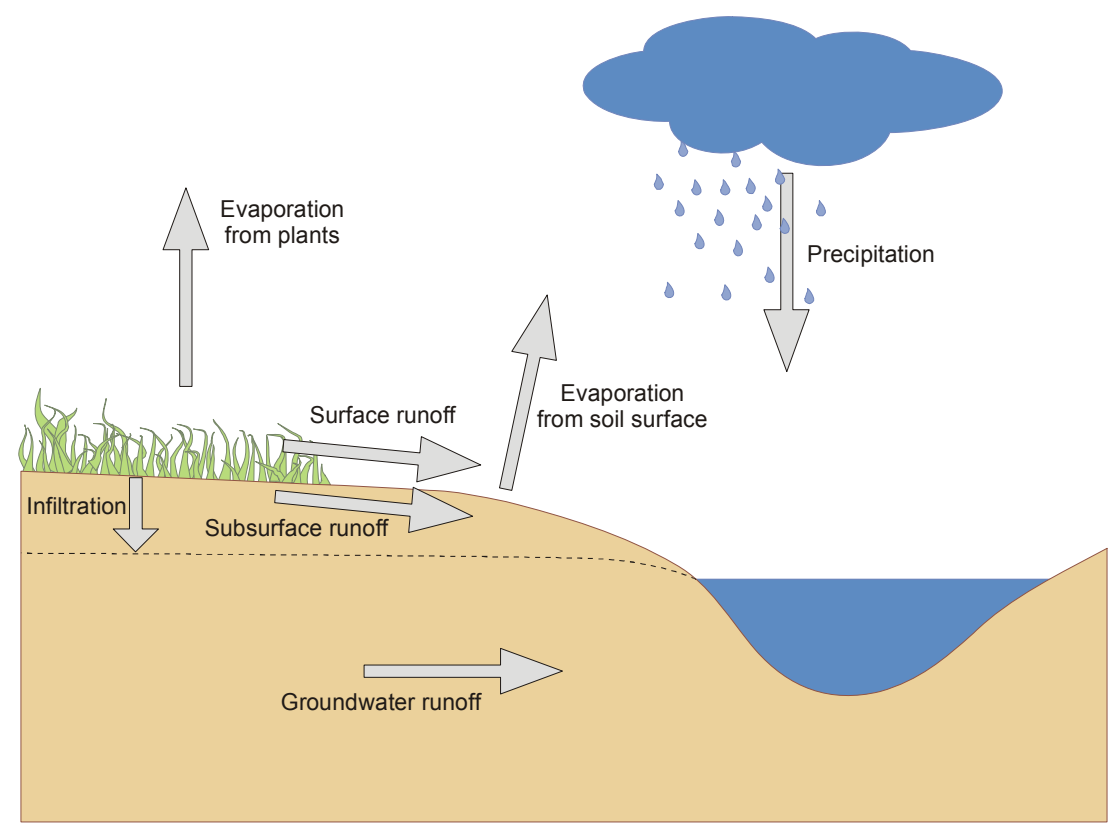

Fig. 3. Processes included in the WISTOO model

- catchment parameters: slope, retention of the cover, coefficient of rainfall division, permeability of surface formations, coefficient of soil porosity, thickness of soil and sub-soil layer,

- distribution of measurement stations and type of observations,

- distribution of control cross-sections in streams,

- hydro-meteorological data.

Calculation procedures used in the model are based on equations and relationships of applied hydrology, so they describe unit runoff processes with the consideration of appropriately integrated physical parameters. This need good recognition of catchment properties and runoff regime since optimisation of parameters describing particular hydrologic processes is not expected in the model. These parameters are established based on information contained in particular thematic layers. Taring of the model is restricted only to the correction of soil parameters. 


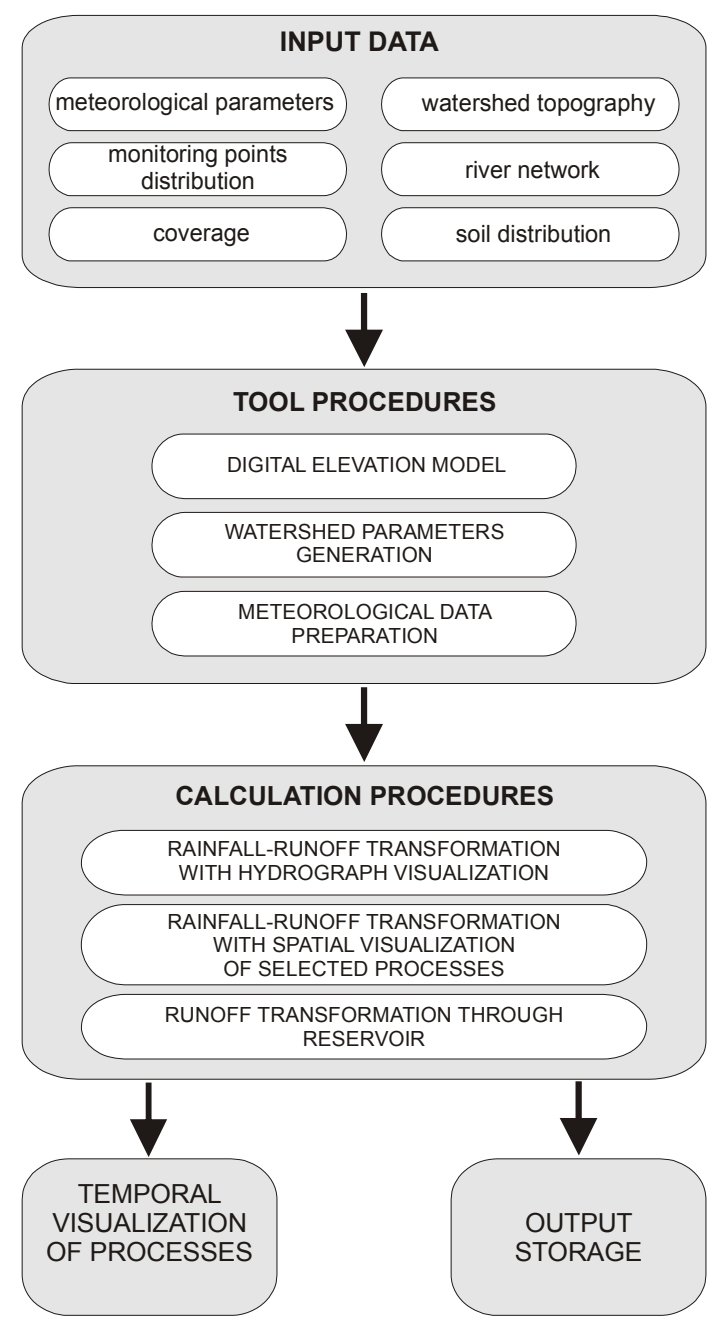

Fig. 4. General structure of the WISTOO computer model

The model gives highly detailed runoff description in both its component elements and spatial scale. Its highly advanced technology is associated with the fact that the solution is "open". This pertains to a possibility of increasing details of the description of rainfall-runoff transformation and to spatial decomposition of this description and differentiation its scale in particular catchment sub-areas.

Structure of the model is based on commonly adopted hydrologic scheme of water cycling in the catchment (Figs 3 and 4) with the following processes involved: interception, evapotranspiration, infiltration, surface runoff, sub-surface and groundwater runoff and outflow from the river network. 


\section{SPATIAL DISTRIBUTION OF METEOROLOGICAL PARAMETERS}

Spatial distribution of meteorological parameters is the basic source of information on meteorological situation in the catchment in a given moment. The distribution is estimated mainly from data gathered in the monitoring system.

Basic method of parameter distribution used in the model is the method of inverse distances. It allows estimating particular meteorological parameters in a form of continuous function. Values measured in the closest stations are used in calculations. The method of reverse distances is based on the assumption that the effect of observation in a measurement point on any other point in the catchement is inversely proportional to the distance between the two points. The distance in this method is a weighing coefficient in measuring the effect of particular measurement stations on the value of spatially distributed parameter. The more the measurement point is distant from calculation points the weaker is its effect. Calculated values of particular meteorological parameters in any point of the catchment are determined from the relationship (Fig. 5):

$$
P_{x}=\frac{\sum_{k=1}^{j} \frac{1}{d_{k}^{n}} P_{k}}{\sum_{k=1}^{j} \frac{1}{d_{k}^{n}}}
$$

where:

$P_{x}$ - the value of distributed parameter in point $i, i=1,2, \ldots, m$,

$P_{k}$ - the value of measured parameter in point $k, k=1,2, \ldots, l$,

$j-$ the number of measurement posts,

$n$ - exponent,

$d_{k}$ - the distance between points $i$ and $k$.

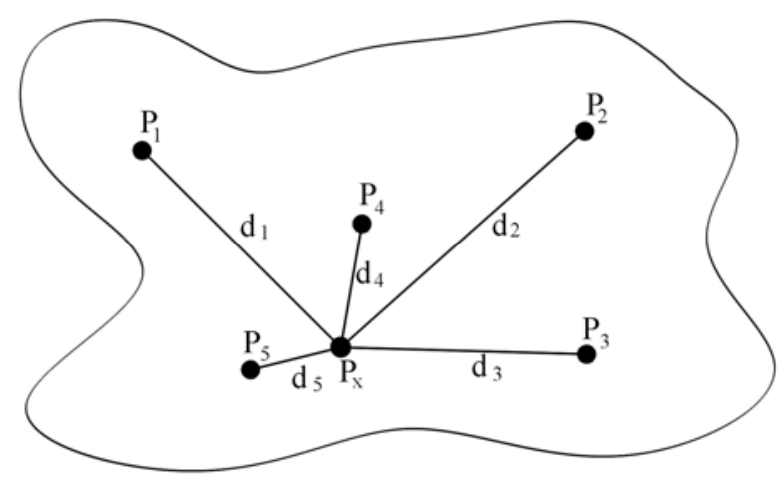

Fig. 5. Inverse weighed distance method 
Exponent $n$ is adopted in relation to land topography. For the Trzebuńka catchment basin $n=1$ was adopted. All observation sites were used in the analysis of spatial distribution of rainfall.

Rainfall in mountain and sub-mountain catchments is observed to depend on the elevation of the measurement points above sea level. The relationship is described by the gradient curve of precipitation.

The amount of rainfall in any point $\mathrm{x}$ with the consideration of the gradient curve is estimated from the relationship:

$$
P_{x}^{\prime}=P x+a\left(H_{x}^{\prime}-H_{x}\right) P_{x}
$$

where:

$P_{x}^{\prime}$ - corrected amount of precipitation, $\mathrm{mm}$;

$P_{x} \quad$ - precipitation estimated with the interpolation method, $\mathrm{mm}$;

$a \quad$ - slope coefficient of the gradient curve, $\mathrm{m}^{-1}$;

$H_{x}{ }_{x}$ - the height of transfer, m;

$H_{x}$ - the height of terrain, $\mathrm{m}$.

The height of transfer $H^{\prime}{ }_{x}$ is the elevation of measurement points above sea level. The value of this parameter is constant for a definite configuration of measurement network and is estimated with the interpolation method by replacing measured precipitation by the elevation of the measurement point.

Slope coefficient of the gradient curve $a$ is estimated from:

$$
a=\frac{P_{i}-P_{i+1}}{\left(H_{i}-H_{i+1}\right) P_{i}}
$$

where:

$P_{i}, P_{i+1}-$ recorded amounts of precipitation for the highest and lowest point, $\mathrm{mm}$;

$H_{i}, H_{i+1}$ - elevations above sea level of the highest and lowest rainfall posts.

\section{SIMULATIONS}

Simulations were performed for data of 2005 and covered the period from $1^{\text {st }}$ May to $30^{\text {th }}$ September. Model verification showed that adopted parameters and the way of calculation were satisfactory. Runoff from the catchment calculated per millimetre of rainfall differed from the measured by $7.3 \mathrm{~mm}$ which gave relative error of $4.1 \%$. The runoff calculated from the model was $186.3 \mathrm{~mm}$ and observed runoff was $179.0 \mathrm{~mm}$. The result was found very good having in mind the time period of 3672 hours for which the calculations were made. 
$5 \times 5 \mathrm{~m}$ raster and quasi-two-dimensional system of water exchange between rasters was used in calculations (Fig. 6). Water exchange in such a system is realised through only one side of the raster according to its inclination.

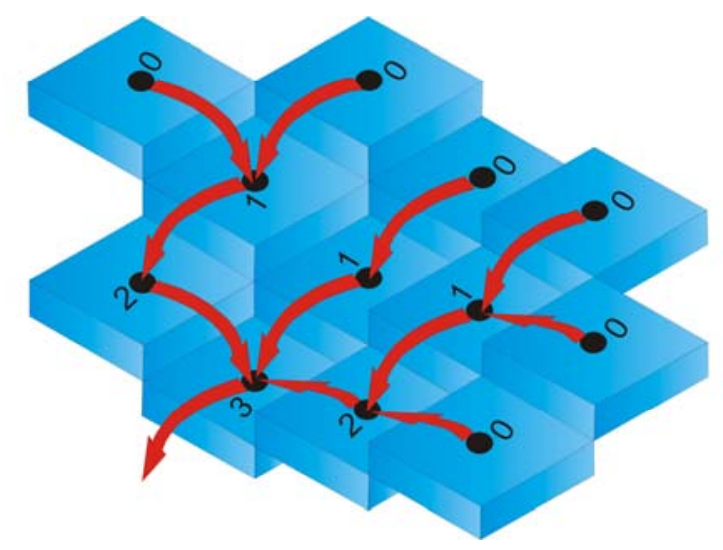

Fig. 6. Water exchange scheme between raster elements in quasi-two-dimensional mode

\section{SPATIAL VARIABILITY OF ATMOSPHERIC PRECIPITATION}

Distribution of rainfalls in mountains is quite variable in space. Many factors are involved in such distribution: elevation of the area, length and width of mountain ranges, location in a definite geographic zone, distance from sea shores and exposition to and direction of air masses. Precipitation on mountain slopes depends on atmospheric circulation and baric systems. Atmospheric precipitation is assumed to increase with elevation. However, mountains form a barrier for air masses flowing from various directions, may change their flow and thus affect uneven distribution of precipitation not always correlated with land configuration.

Main factors generating rainfall distribution in the area of the Trzebuńka catchment were analysed in this study. Performed analyses had to establish how big was the effect of elevation and exposition of mountain slopes and direction of air masses on precipitation.

\section{METHODS}

Rainfall monitoring began in 2005 by placing 4 rain gauges in longitudinal profile and 8 rain gauges in crosswise profile of the catchment in its middle part. Difference in elevations between extreme sampling points was $435 \mathrm{~m}$. The lowest site of rain gauge was in the station Klebertówka $300 \mathrm{~m}$ a.s.l., the highest - on top of the southern slope in Jaworzyny $-735 \mathrm{~m}$ a.s.l. as depicted in Fig. 7 and 8. 


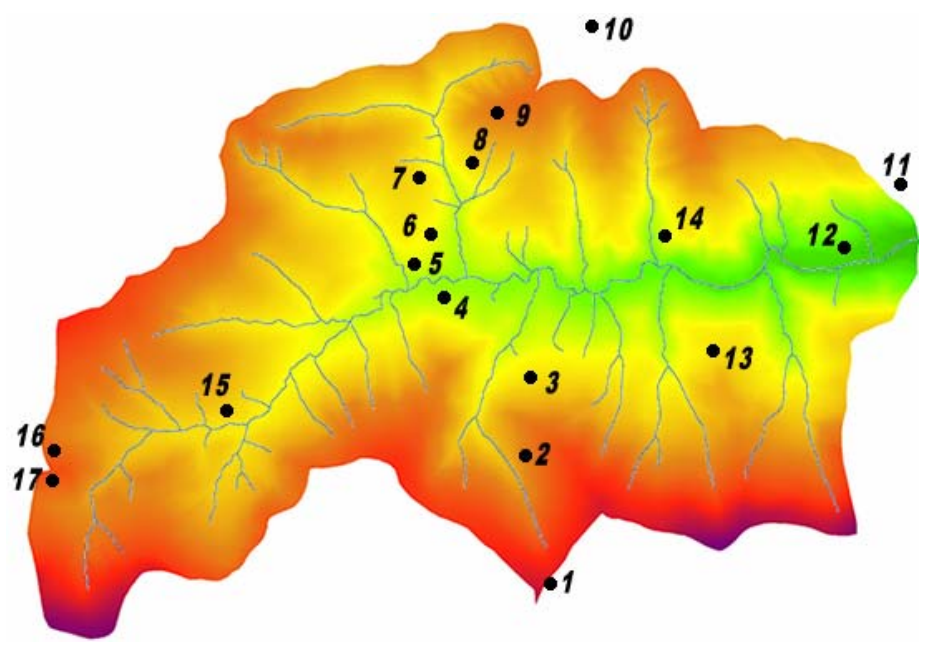

Fig. 7. The Trzebuńka stream with Hellmann rain gauges distribution

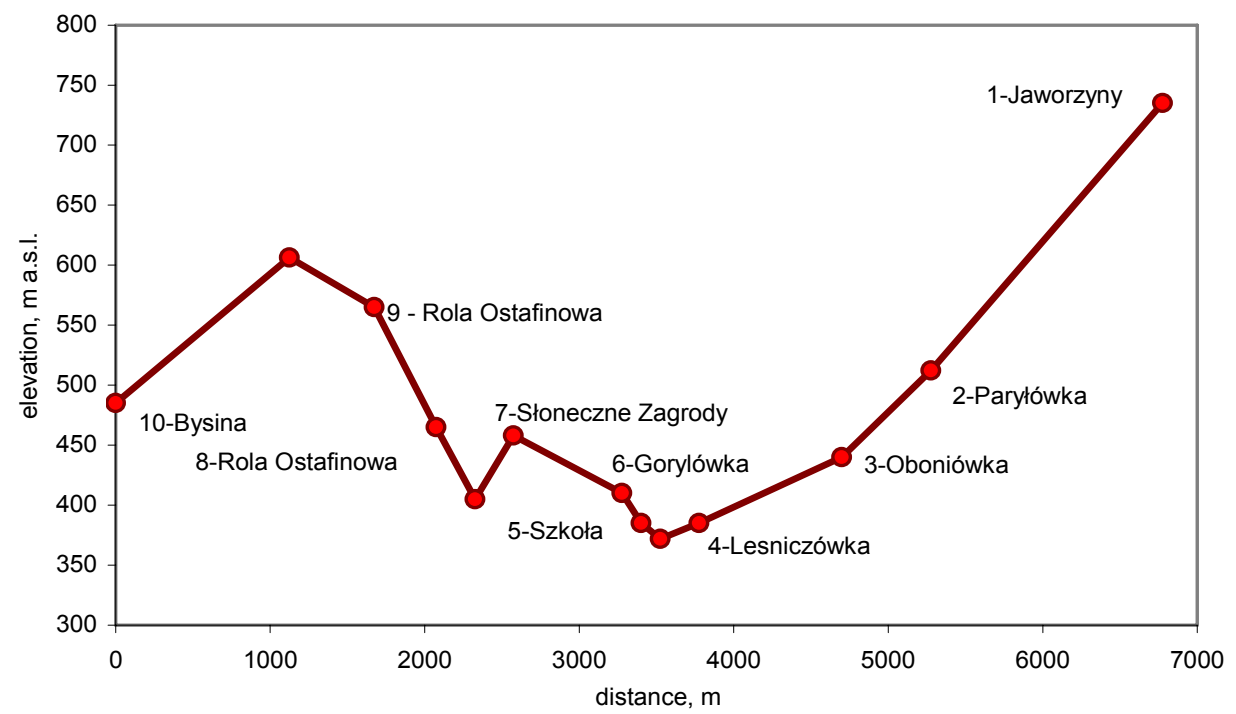

Fig. 8. Distribution of rain gauges in the cross-section of the Trzebuńka stream catchment

RELATIONSHIP BETWEEN RAINFALL AND ELEVATION ABOVE SEA LEVEL AND OROGRAPHY

The effect of topography on rainfall

According to LAMBOR (1971) an increase in elevation above sea level favours the condensation of water vapour in the air hence at higher elevations the rainfalls 


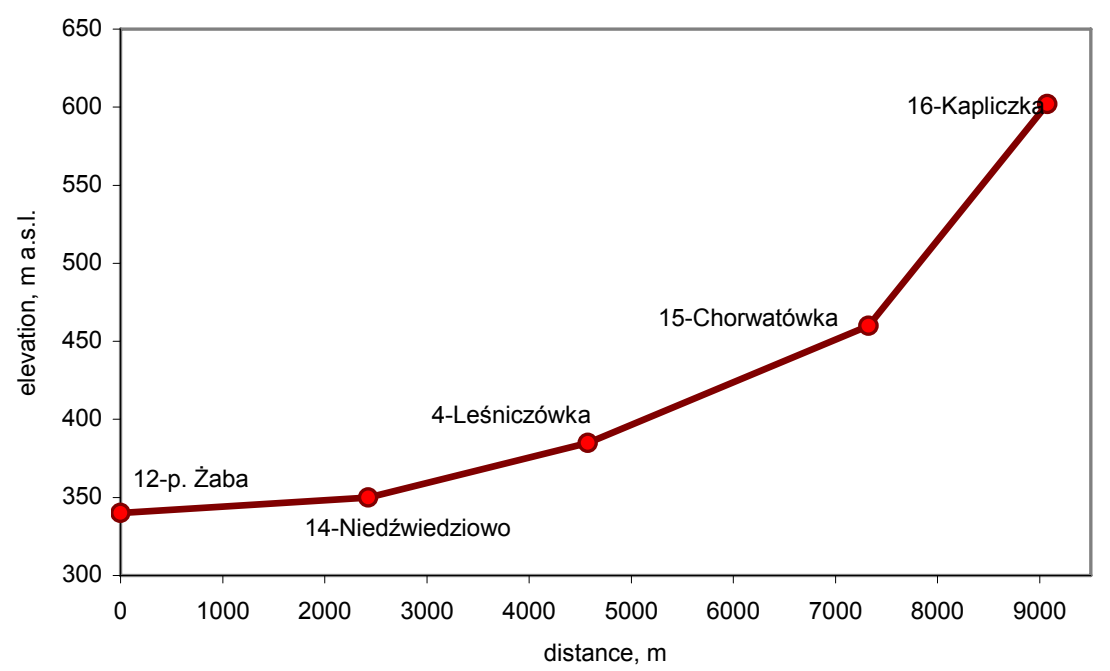

Fig. 9. Distribution of rain gauges in longitudinal profile through the Trzebuńka stream catchment

are larger, which is particularly visible in analysing monthly and annual sums of precipitation.

Annual sums and sums from winter half-year are correlated with elevation while the sums of summer half-year do not show such relationships. The increase of rainfall with elevation is not uniform due to important role of stable factors associated with land relief and variable (atmospheric) factors (TREPIŃSKA, 2002).

Measurements of rainfall in longitudinal and crosswise profiles of the catchment collected from May till September 2005 were used in analyses (Fig. 9). There was no correlation between land elevation and total sum of precipitation recorded in all rain gauges (Fig. 10).

The effect of orography on rainfall

TREPIŃSKA (2002) is of the opinion that precipitation in mountains depends mainly on elevation. However, land relief and slope exposition play important role. It is often so, that highly elevated but shielded from wind areas receive smaller rainfalls.

According to BAJKIEWICZ-GRABOWSKA (1999) rainfall distribution in mountain areas is affected by slope exposition. Windward side receives more rainfall due to condensation of water vapour in air masses. On the leeward side of the mountain there is a rainfall shadow characterised by smaller precipitation.

NIEDŹWIEDŹ (1981) demonstrated climatic asymmetry between slopes of northern and southern exposition. Exposition to the flow of humid air masses has also a substantial impact on climatic conditions. Northern slopes of the Carpathians show higher humidity than the southern slopes. There is a possibility of large rainfalls on windward side of mountains and smaller - on flat leeward side areas - the 


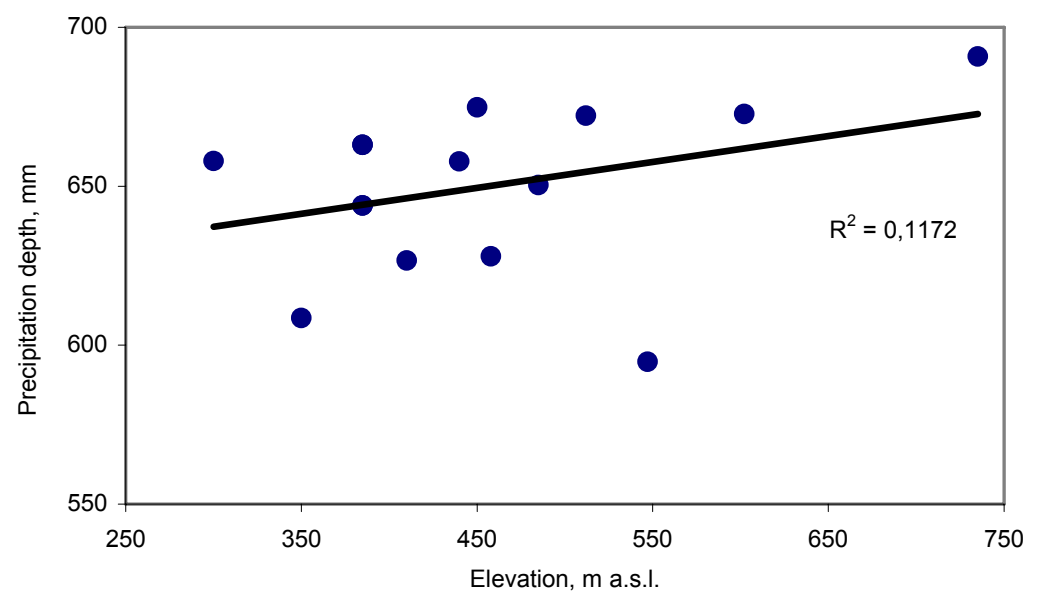

Fig. 10. Relationship between precipitation and elevation for all sampling points in the year 2007

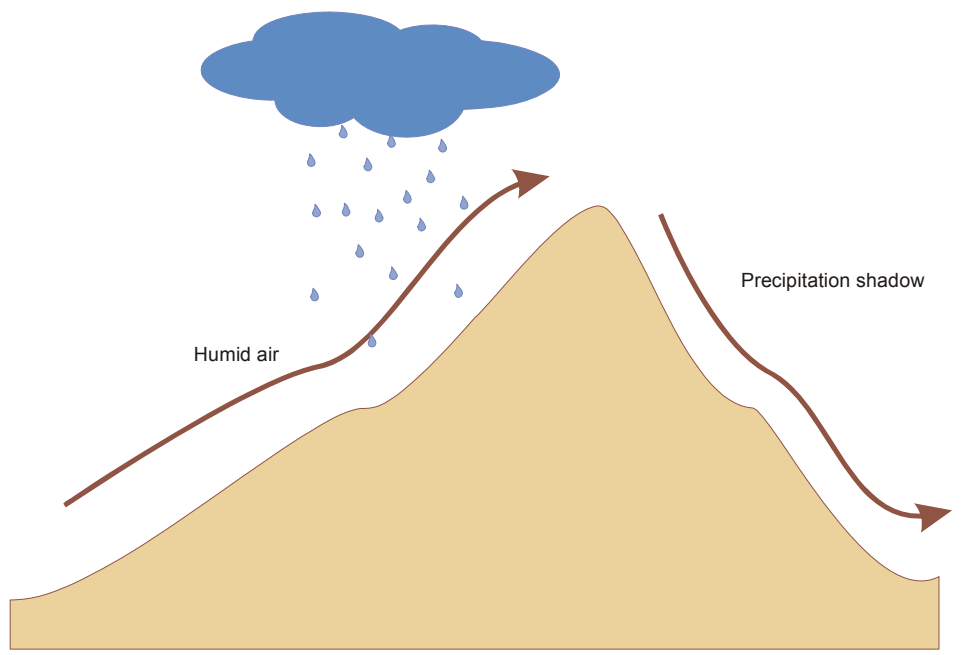

Fig. 11. Orographic precipitation and the formation scheme of precipitation shadow

so-called "rainfall shadow" caused by shielding the area by hills. Areas situated in the precipitation shadow are also called "orographically dry areas" (Fig. 11).

The classification of circulation types proposed by NIEDźWIEDź (1981) was used in the analysis of relationship between precipitation and atmospheric circulation. The direction of advection was marked with commonly used letter code with the index "a" for anticyclone and "c" for cyclone systems.

Types of meteorological situations acc. to Niedźwiedź:

- Na, Ne - situation with air advection from north,

- NEa, NEc - situation with air advection from north-east, 
- Ea, Ec - situation with air advection from east,

- SEa, SEc - situation with air advection from south-east,

- Sa, Sc - situation with air advection from south,

- SWa, SWc - situation with air advection from south-west,

- Wa, Wc - situation with air advection from west,

- NWa, NWc - situation with air advection from north-west,

- Ca - central anticyclone situation, no advection, centre of the anticyclone over southern Poland,

- Ka - anticyclone ridge, sometimes several indistinct centres or blurred area of higher pressure, the axis of the high pressure ridge,

- Cc - central cyclone situation, cyclone centre over southern Poland,

- Bc - cyclonic trough, blurred area of low pressure or the axis of cyclone trough with various directions of advection and systems of fronts separating different air masses,

- $\mathbf{X}$ - non-classified situations and baric saddles.

Rainfall distribution across the catchment is different for each meteorological type with significant role of terrain orography. Measured data were analysed with respect to the types of circulation and slope exposition in eight directions. Wind rose in the study period is presented in Fig. 12.

a)

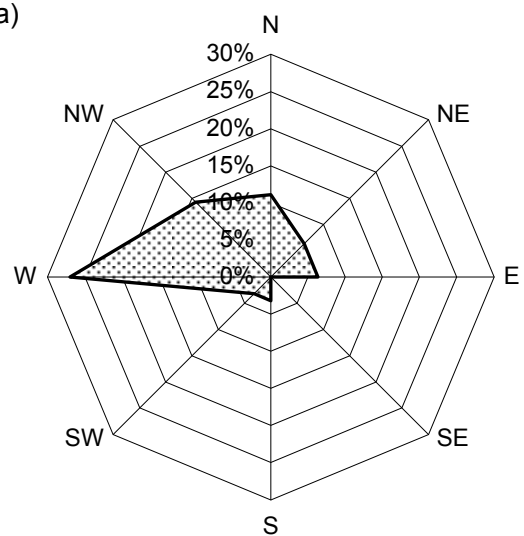

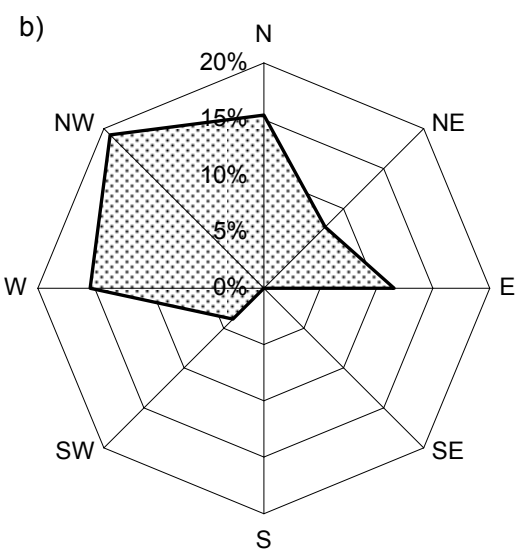

$S$

Fig. 12. Wind rose for days with precipitation sum exceeding $0.1 \mathrm{~mm}$ (a) and $5 \mathrm{~mm}$ (b)

Theoretical assumptions were confirmed and clear relationships between the total sum of precipitation and elevation were found for northern circulations - Figs. 13 and 14.

During the westerly inflow of air masses precipitation was evenly distributed over the catchment. The amount of rainfall was increasing with the terrain elevation on northern slope slightly lower precipitation was observed on southern slope than on the opposite. The former also increased with elevation. 


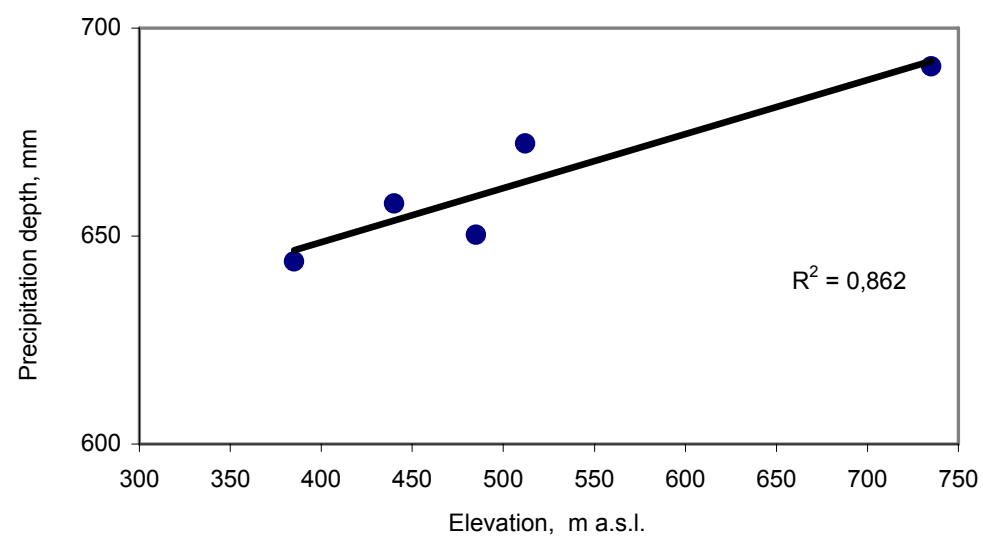

Fig. 13. The relationship between precipitation and elevation for slopes with $\mathrm{N}$ and $\mathrm{NW}$ aspect in the case of northern circulations

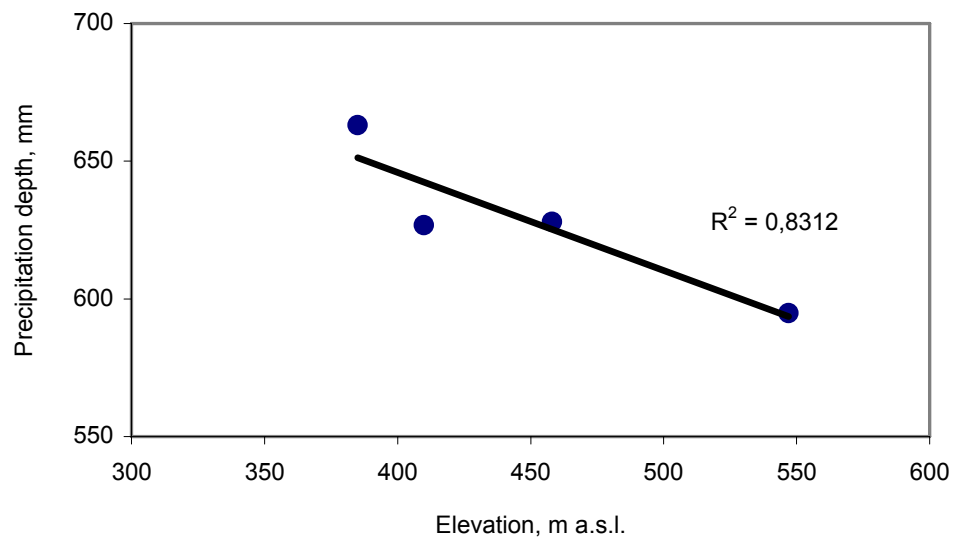

Fig. 14. The relationship between precipitation and elevation for slopes with SW and SE aspect in the case of northern circulations

Air inflow from east caused fairly even rainfall on both slopes, higher on eastern edges of the catchment and slightly higher on eastern slopes. On both sides of the catchment the rainfall increased with elevation.

Mean precipitation was estimated for established relationships for particular atmospheric circulations and slope expositions and obtained values were compared with precipitation calculated from the values measured in rainfall gauges (Fig. 15). Mean precipitation in the catchment was lower by 33\% than that calculated with the assumption that atmospheric circulation had no effect on its spatial distribution. The sum of atmospheric precipitation with the consideration of atmospheric circulation was $517 \mathrm{~mm}$. This constituted only $6 \%$ error but generated the increase of runoff by the same values. For studied catchment it does not matter which factors 


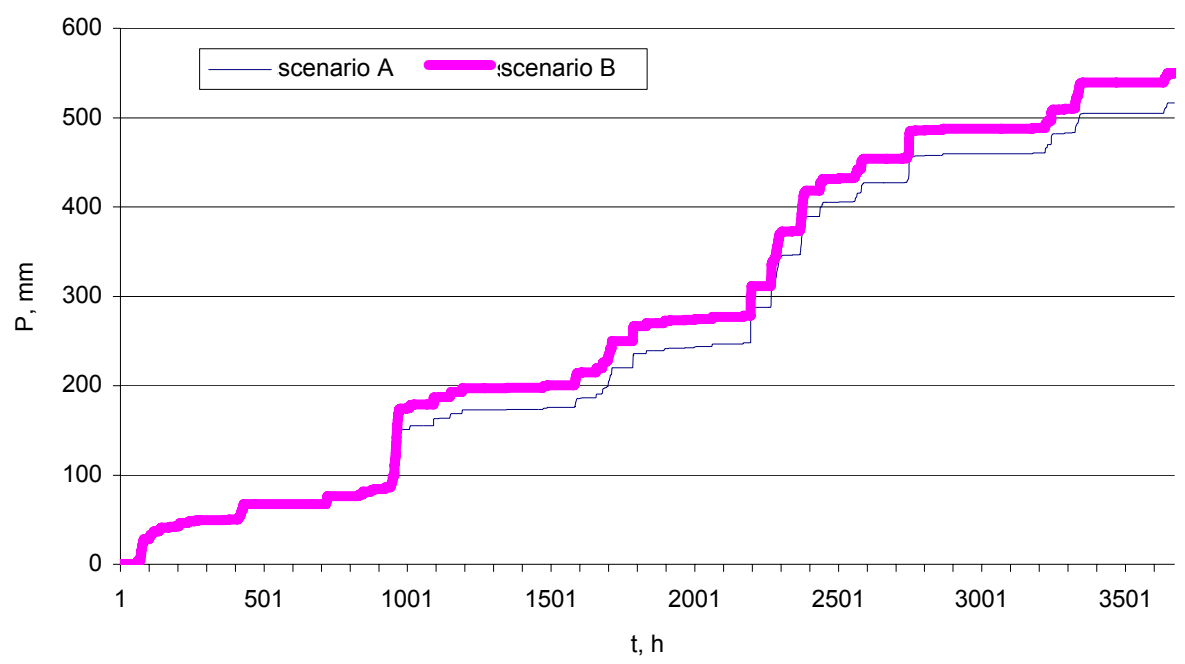

Fig. 15. The curves of precipitation sums considering atmospheric circulationscenario A and without atmospheric circulation - scenario B

are considered in analysing spatial distribution. It matters when assessing the runoff which is higher than the measured. It should be expected that in taring the model in which spatial distribution of rainfall was estimated without considering atmospheric circulation, the excess of rainfall had to be "consumed" by increasing losses for evaporation.

\section{THE EFFECT OF FOREST LITTER INTERCEPTION ON WATER BALANCE IN A CATCHMENT}

According to Mała... (1980), the amount of litter produced in deciduous forests of Central Europe ranges between 3 and $4.5 \mathrm{t} \cdot \mathrm{ha}^{-1}$ and in coniferous forests from 1.5 to $7 \mathrm{t} \cdot \mathrm{ha}^{-1}$ and these amounts vary from year to year. "Shady" species (fir, spruce, beech, hornbeam) produce more litter than photophilic species (ash, aspen, birch, pine, larch). The leaves of ash, elm, hornbeam, alder, linden and maple trees decompose fastest; those of oak, birch and aspen trees - slower and the leaves of beech, fir, spruce, pine and larch decompose very slowly.

Forest litter plays important role in forest community not only because of the amount of retained rainfall water but also by affecting physical, chemical and biological soil properties. Forest litter is a kind of the regulator of soil climate: it accumulates large water resources gradually released to soil; hampers gas exchange between the soil and the atmosphere and affects thermal conditions. 
CHARACTERISTICS OF FOREST LITTER IN SELECTED SITES OF THE TRZEBUŃKA CATCHMENT

The catchment of the Trzebunka stream is forested in 51\%. A set of measurements was performed in forest habitats to characterise forest litter in the Trzebuńka catchment. In total, 14 sites in various places of the catchment were selected. The litter thickness was measured in the intersections of the net of $2 \mathrm{~m}$ squares in most representative $10 \times 10 \mathrm{~m}$ plots. Mean litter thickness for a given plot was calculated from measurements in 25 points. In total the litter thickness was measured in 350 points. Mean litter thickness $(h)$ for the Trzebuńka catchment was $4.1 \mathrm{~cm}$. Maximum thickness was $8 \mathrm{~cm}$ (the Żabicki stream catchment) and the minimum - 1.5 $\mathrm{cm}$ (HOMA, OSUCH, 1997). Fig. 16 presents the points of measurements of forest litter thickness.

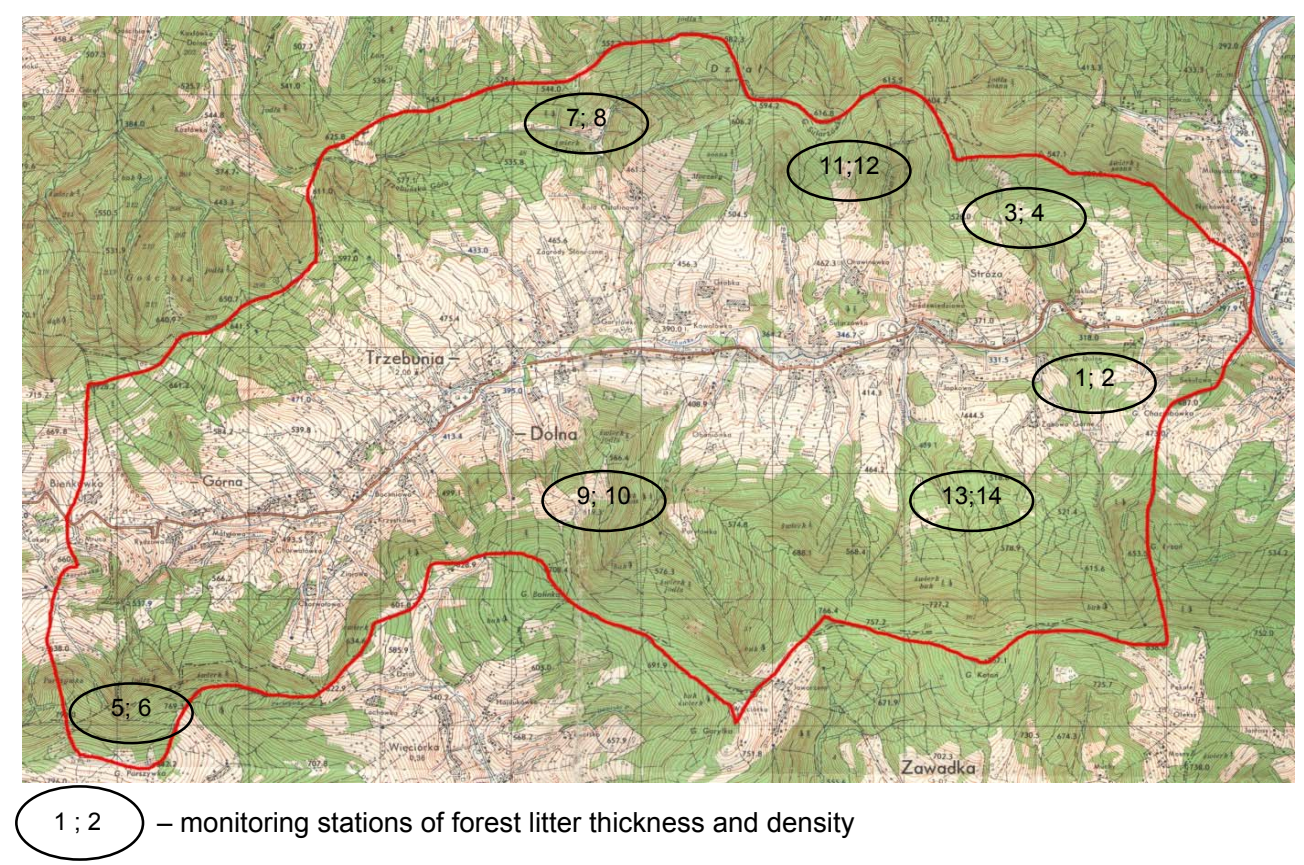

Fig. 16. Forest location and monitoring stations in the Trzebuńka stream catchment

Two separate components can be distinguished from among obtained results:

a) free water retention,

b) retention of bound water (Fig. 17).

Therefore, total retention of water in forest litter in time $t_{i}$ is the sum of water retained earlier (before rainfall) $r_{o}$, bound water retention $R_{z i}$ and free water retention $R_{w i}$. 


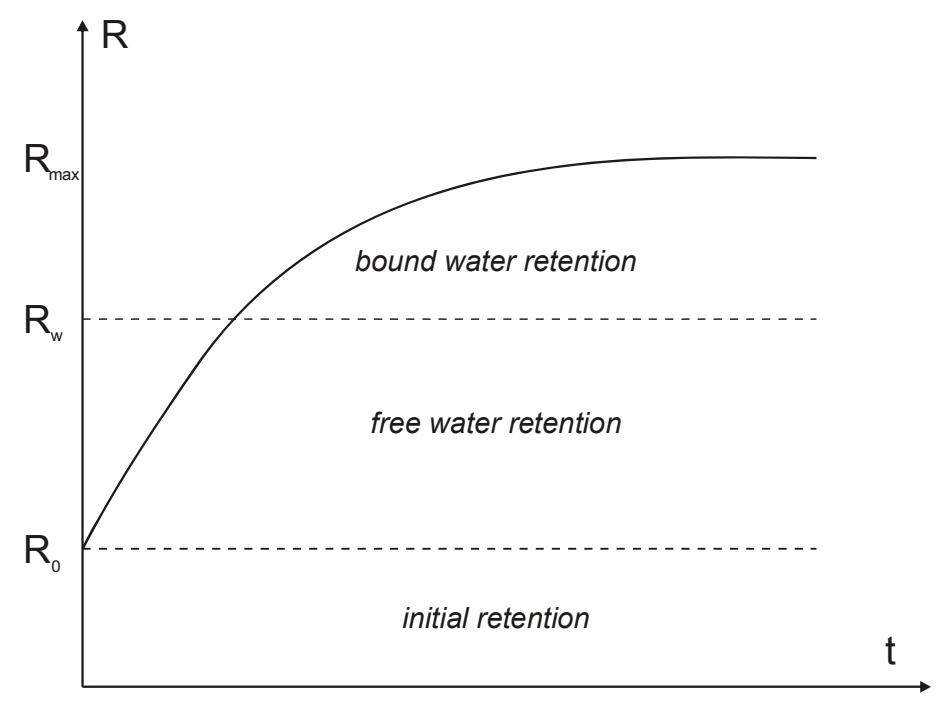

Fig. 17. General scheme of water retention in forest litter divided into basic processes

$$
R_{t i}=r_{o}+R_{z i}+R_{w i}
$$

Until elaboration of mathematical model of evaporation from forest litter in the other study, the relationships presented in Fig. 18 served to estimate the losses associated with evaporation from litter in monthly water balance of the catchment. Having basic meteorological parameters like: precipitation, temperature and relative air humidity one may estimate evaporation from forest litter.

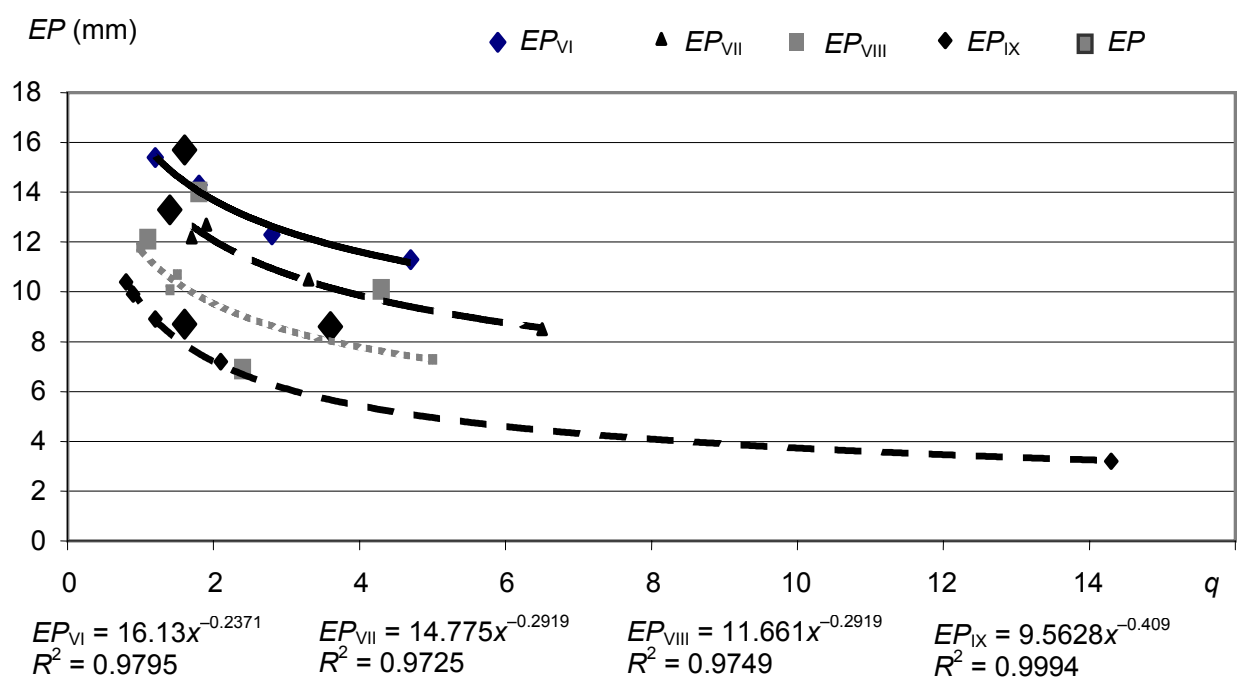

Fig. 18. The relationship between humidity index $q$ and evaporation $E P$ (in $\mathrm{mm}$ ) from forest litter 


\section{SIMULATIONS}

In the WISTOO model the interception was described in a standard set where net precipitation was an outcome of through-flow precipitation and water flowing on plant cover (Fig. 19). Forest litter was additionally introduced to elaborated model application whose schematic description is given in Fig. 20.

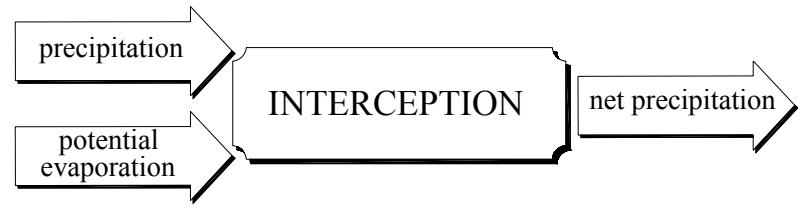

Fig. 19. Traditional interception calculation scheme

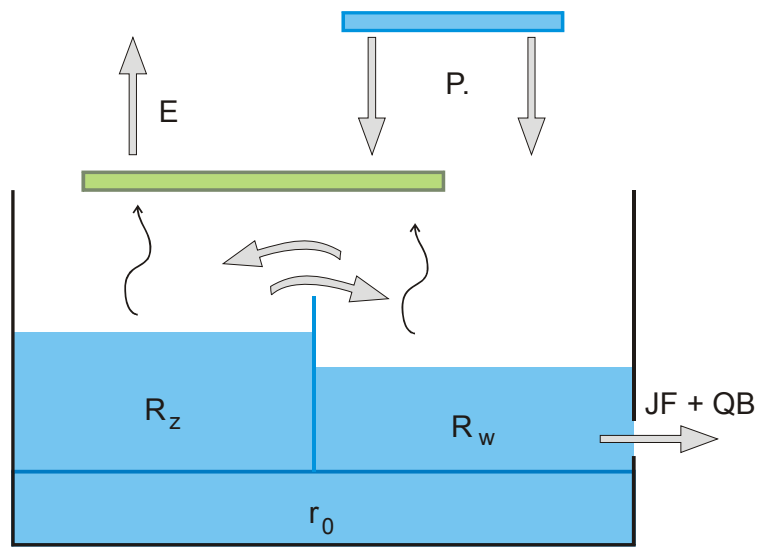

Fig. 20. Calculation scheme of the interception of forest litter; $P$-precipitation, $E$ - evaporation, $J F$ - infiltration, $Q B$ lateral outflow, $R_{z}$ - bound water reservoir capacity, $R_{w}$ - free water reservoir capacity, $r_{0}$-water stored in forest litter before precipitation

Fig. 21 presents summary course of mean net precipitation. Important in this case is a comparison of scenario A (net precipitation with forest litter considered) with scenario $\mathrm{C}$ (the effect of forest litter neglected). In this general approach, net precipitation increased by $37 \mathrm{~mm}$ during the study period of 6 months. Initial water retention in forest litter increased by $2.5 \mathrm{~mm}$ from $8.2 \mathrm{~mm}\left(1^{\text {st }}\right.$ May) to $10.7 \mathrm{~mm}$ $\left(30^{\text {th }}\right.$ September).

To sum up, the interception of forest litter has significant effect that should be considered in the water balance. One should remember that forests cover more than $50 \%$ of the catchment area and the effect of forest litter will increase proportionally to the afforested area. Total interception (interception of the forest, litter and under- 


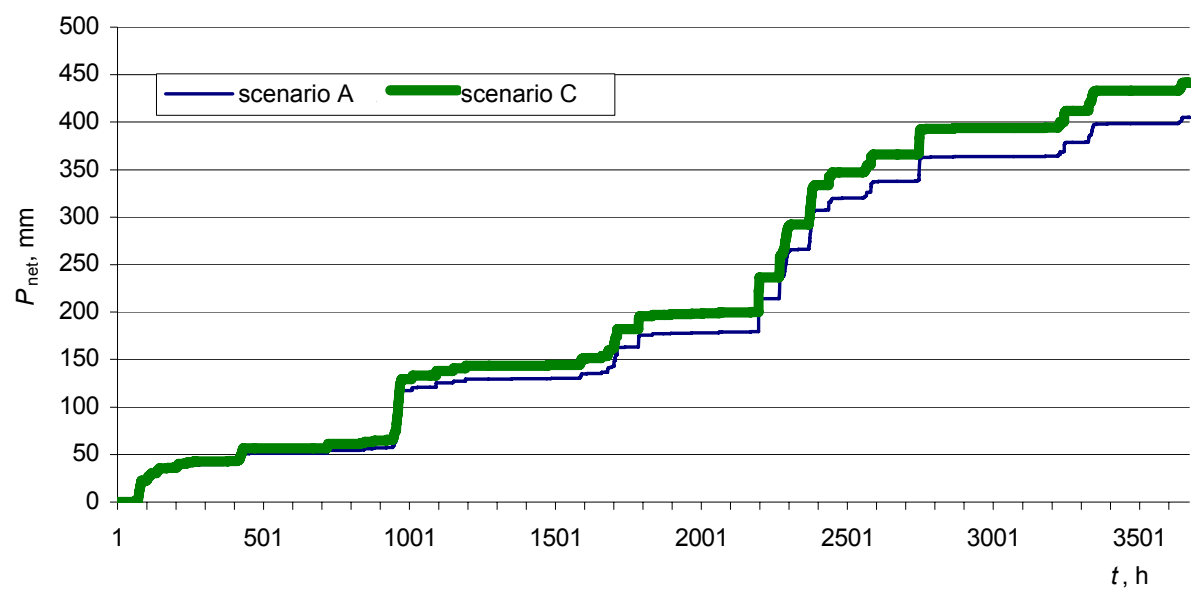

Fig. 21. Summary changes of net precipitation: scenario A - considering forest litter in calculations; scenario $\mathrm{C}-$ without the effect of forest litter

growth) at present land use in the Trzebuńka stream catchment generates losses on evaporation equal $112 \mathrm{~mm}$ i.e. over $21 \%$ of atmospheric precipitation.

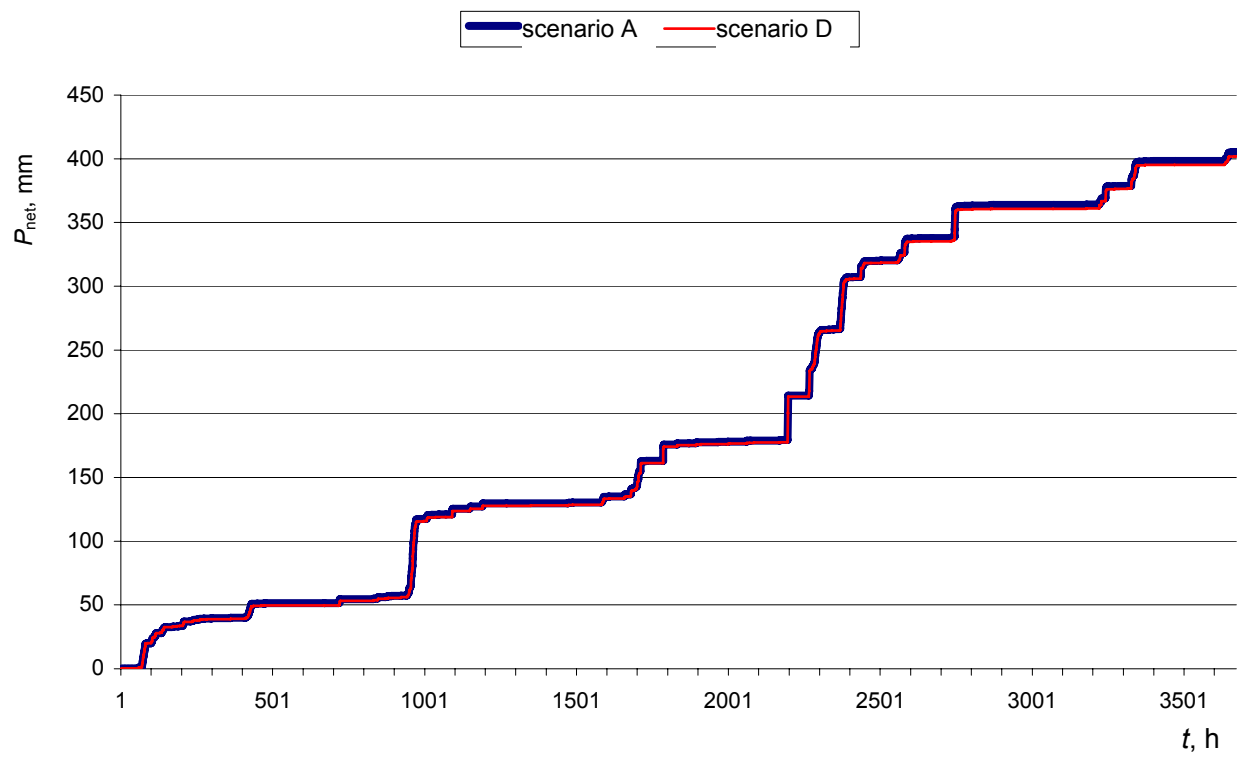

Fig. 22. Summary changes of net precipitation; Scenario A - forest interception considering forest litter, Scenario D - forest litter interception after forest cut-off 
HYPOTHETICAL SCENARIO - INTERCEPTION OF FOREST LITTER IS PRESENT AFTER FOREST CUTTING

Proposed scenario had to illustrate hypothetical situation when forest was cut but forest litter remained in the former spatial distribution (Fig. 22). Evaporation in forest is limited by shading from tree crowns and by decreased drying power of winds. In adopted scenario evaporation from forest litter proceeds as if from open space. Evaporation is calculated in a way similar to that for plant interception i.e. in proportion to presently retained water and maximum retention capacity. At such assumptions, mean net precipitation in the catchment was smaller by $3 \mathrm{~mm}$ than the net precipitation for actual plant cover. This shows potential possibilities comparable with the interception of forest vegetation which might be limited only by forest microclimate.

\section{CONCLUSIONS}

Based on direct field measurements and computer simulations with the integral model of distributed parameters it is possible to conclude that:

1. Mean precipitation in the Trzebuńka stream catchment considering the effect of circulation on spatial variability is lower by more than $20 \%$ than that without involvement of this effect.

2. One may expect that the error of estimation of mean precipitation in the catchment could be higher in the case of much lower number of measurement posts.

3. Maximum retention capacity of forest litter is 4 to 5 times that of the tree stand. However, actual available retention of forest litter is smaller since this litter contains the so-called initial retention which is 10 to $30 \%$ of the maximum. The process of water retention and release is different in forest litter and in tree stand. Tree stand has usually at its disposal full retention capacity and after its fulfilment with rainfall it quickly restores its possibility to retain water. Filled pool of forest litter needs several (7-9) rainless days to recover to the initial status from before the rainfall. Therefore, during interrupted rainfalls the tree stand may dispose its retention capacity several times while forest litter filled with water is not able to rapidly incorporate next rainfalls. As a result, the effect of forest litter and tree stand is comparable and compensated.

4. Omitting the effect of atmospheric circulation and interception of forest litter when estimating mean precipitation in the catchment may generate errors. For water balance for the summer half-year of 2005 it means rainfall overestimation by $70 \mathrm{~mm}$. 


\section{REFERENCES}

1. BajkiEwicZ-Grabowska E., MikUlski Z., 1999. Hydrologia ogólna. Wyd. 3. Warszawa, PWN.

2. Hess M., 1965. Piętra klimatyczne w polskich Karpatach Zachodnich. Zesz. Nauk. UJ Pr. Geogr., 12.

3. GĄDEK W., 2002. Matematyczny model odpływu ze zlewni z zastosowaniem zdekomponowanej przestrzennie siatki obliczeniowej. Kraków, PKrak.

4. HomA A., 1995. Charakterystyka fizjograficzna zlewni Trzebuńka. W: Badania naukowe w hydrologicznej stacji badawczej w Stróży. Pr. zbior. Red. B. Osuch. Monogr., 188. Kraków, PKrak.

5. Homa A., Osuch B., 1997. Wypełnienie zbiornika retencyjnego ściółki leśnej. W: Współczesne problemy inżynierii wodnej. III Konf. nauk., 23-25 kwietnia 1997, Wisła. Kraków, PKrak.

6. LAMBOR J., 1971. Hydrologia inżynierska. Warszawa, Arkady.

7. Mała encyklopedia leśna, 1980. Warszawa, PTLeś, PWN.

8. NiEDźwIEDŹ T., 2007. Kalendarz typów cyrkulacji dla Polski Południowej. Zbiór komputerowy. Sosnowiec, UŚl. Kat. Klimatol.

9. NIEDŹWIEDŹ T., 1981. Sytuacje synoptyczne i ich wpływ na zróżnicowanie przestrzenne wybranych elementów klimatu w dorzeczu Górnej Wisły. Kraków, UJ.

10. OZGA-ZieliŃSKa M., GĄDEK W., KSIĄŻYŃSKi K., NACHLIK E., SZCZEPANEK R., 2002. Hydrology. Mathematical model of rainfall-runoff transformation - WISTOO. In: Models of large watershed hydrology. Eds. V.P. Singh, D.K. Frevert. Littleton, Colorado, Water Res. Publ., LLC.

11. TREPIŃSKA J., 2002. Górskie klimaty. Kraków, IGiGP UJ.

\section{STRESZCZENIE}

\section{Metodyka oceny ksztaltowania elementów bilansu wodnego zlewni zalesionej}

Słowa kluczowe: bilans wodny, intercepcja, opad, retencja

W pracy przedstawiono podstawowe procesy hydrologiczne, biorące udział w transformacji opadu w odpływ w zlewni badawczej potoku Trzebuńka. W celu określenia podstawowych parametrów hydrologicznych na terenie zlewni tego potoku przeprowadzono badania terenowe. Między innymi podjęto próbę ustalenia wpływu cyrkulacji atmosfery na przestrzenny rozkład opadu, określono wpływ roślinności leśnej, upraw niskich oraz retencji ściółki i retencji powierzchni terenu na ilość strat wody w zlewni. Określone zostały również wielkości retencji wody w glebie. Opracowany matematyczny model transformacji opadu w odpływ o parametrach rozłożonych został wykorzystany do przeprowadzenia różnych symulacji. Między innymi posłużył do oceny wpływu: cyrkulacji atmosferycznej i przestrzennego rozkładu opadu na ogólny bilans zlewni; pokrywy roślinnej wraz z retencją ściółki leśnej na kształtowanie odpływu ze zlewni oraz retencji samej ściółki - scenariusz hipotetyczny, który może zaistnieć w przypadku wycięcia lasu.

Reviewers:

Dr. Jan Tyszka

Prof. Józef Suliński 